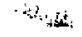

\title{
P-14 HYDROCARBON SEEPS IN AL QARQAE ARCH, NW LIBYA, SPATIAL DISTRIBUTION AND GEOCHEMICAL ANALYSIS :
}

Y.A. AL FASATW1', M.S. HROUDA² and M.M. ELKELANI" International Institute For Aerospace and Earth Sciences, PO Box 6, 7500 AA Enschede, The Netherlands Petroleum Research Center

\begin{abstract}
Residual petroliferous materials are often indications that hydrocarbons have at some times passed through particular rock types, formations or structures. The study of the nature of hydrocarbon seeps can help to provide a better understanding of the hydrocarbon trapping potential of an area.
\end{abstract}

Several hydrocarbon seeps located along the southern edge of Al Qarqaf Arch were observed and studied. The primary objective was to analyze the spatial distribution and the geochemistry of the hydrocarbon seeps in Al Qarqaf Arch area using remote sensing and geochemical analysis of the soil. The approach used in this study was an empirical analysis of known area of historical seeps of hydrocarbons, which was assumed to have the potential for current seeps activity. Landsat TM and Spot XS image of the area was used for lineament analysis and lithological mapping for the areas of hydrocarbon seeps. Field based methods were used to supplement the study, and to provide independent validation of the result.

The area of study is located $90 \mathrm{~km}$ north of the city of Sabha (Figures 1), near the villages of Quttah and Brak. Geologically the area belongs to the southern part of Al Qarqaf Arch and the northern rim of the Murzuq Basin.

Soil samples of the hydrocarbon seeps were collected and geochemically analyzed (Figure 2 and Table1). Nine sites were selected where anomalously, high vertical hydrocarbon seepage from underlying hydrocarbon reservoirs could have caused surface and near surface geochemical change in the soils. Some of these seeps were associated with contaminated water wells. (Water wells containing oil).

\section{CONCLUSIONS AND IMPLICATIONS FOR HYDROCARBON EXPLORATION}

1. The fractionation data that are shown in Table 1 indicates a high proportion of asphaltenes (64\%-91\%), depletion in saturates $(1.9 \%-18 \%)$, and aromatics (4\%-18\%). These data refer to heavy asphaltic crude result from severe biodegradation, which was reinforced by water washing, oxidation and escape of volatiles.

2. The presence of the seeps along a well-defined NE-SW trending normal fault almost parallel to the orientation of Al Qarqaf Arch reinforces the probability that the oil has migrated from the 
3.

northern flank of the Murzuq Basin. Looking at the distance to the nearest oil field in the Murzuq Basin one may conclude that other fields may exist in the intervening area.

3. Both groups of hydrocarbon seeps (Quttah and Brak areas) are localized near the contact between the unconformable Devonian Formations (Quttah and Debdab Formations).

4. The hydrocarbon seeps in the area of Quttah are only known from literature survey. This study indicates that the hydrocarbon seeps are spread over a larger area.

5. Both the spatial distribution of the hydrocarbon seeps and the results of geochemical analysis indicate the importance of structural and stratigraphic: relationships, in particular around basement arches. These arches were effective in localizing truncation, unconformities and onlap of depositional sequences, and are likely to be focal points for hydrocarbon migration, accumulation, and seepage.

\section{Recommendations}

1. Detailed oil-oil correlation between the samples of the hydrocarbon seeps and crude oil of different reservoirs in the Murzuq Basin to determine the source of hydrocarbons of the seeps.

2. Hyperspectral remote sensing and analysis of the area of hydrocarbon seeps to study the capability of this technology in mapping of hydrocarbon seeps in arid environment.

\begin{tabular}{|c|c|c|c|c|c|c|c|c|}
\hline \multirow{2}{*}{$\begin{array}{c}\text { Sample } \\
\text { No }\end{array}$} & Location & \multicolumn{4}{|c|}{ Bulk Parameters } & \multicolumn{3}{c|}{ C15+ Composition \% } \\
\cline { 3 - 9 } & & $\begin{array}{c}\text { TOC } \\
\%\end{array}$ & S1 & S2 & $\begin{array}{c}\text { Total } \\
\text { Extract } \\
\text { (PPM) }\end{array}$ & $\begin{array}{c}\text { SAT } \\
\%\end{array}$ & $\begin{array}{c}\text { AROM } \\
\%\end{array}$ & $\begin{array}{c}\text { POLAR } \\
+ \\
\text { ASPHA } \\
\text { LT }\end{array}$ \\
\hline S1 & BS 1 & 0.028 & 1.03 & 4.43 & 336.5 & 1.9 & 11.8 & 86.4 \\
\hline S2 & BS2 & 0.018 & 1.42 & 3.20 & 268 & - & - & - \\
\hline S3 & BS3 & 0.028 & 1.27 & 1.82 & 244 & - & - & - \\
\hline S4 & BS4 & 0.022 & 1.18 & 3.54 & 1394.7 & 18 & 12 & 64 \\
\hline S5 & Q1 & 0.024 & 0.10 & 0.47 & - & - & - & - \\
\hline S6 & B1 & 0.29 & 1.84 & 3.78 & 1567 & 5 & 4 & 91 \\
\hline S7 & Q2 & 0.015 & 1.0 & 0.95 & 345 & - & - & - \\
\hline S8 & BS5 & 0.022 & 0.26 & 0.37 & - & - & - & - \\
\hline S9 & Q3 & 0.022 & 0.18 & 0.98 & - & - & - & - \\
\hline
\end{tabular}

Table 1: Location, Bulk Parameters and Composition of oil seep samples of the area of study. (BS: Bir Shirhan (near Quttah), Q: Quttah and B: Brak). 


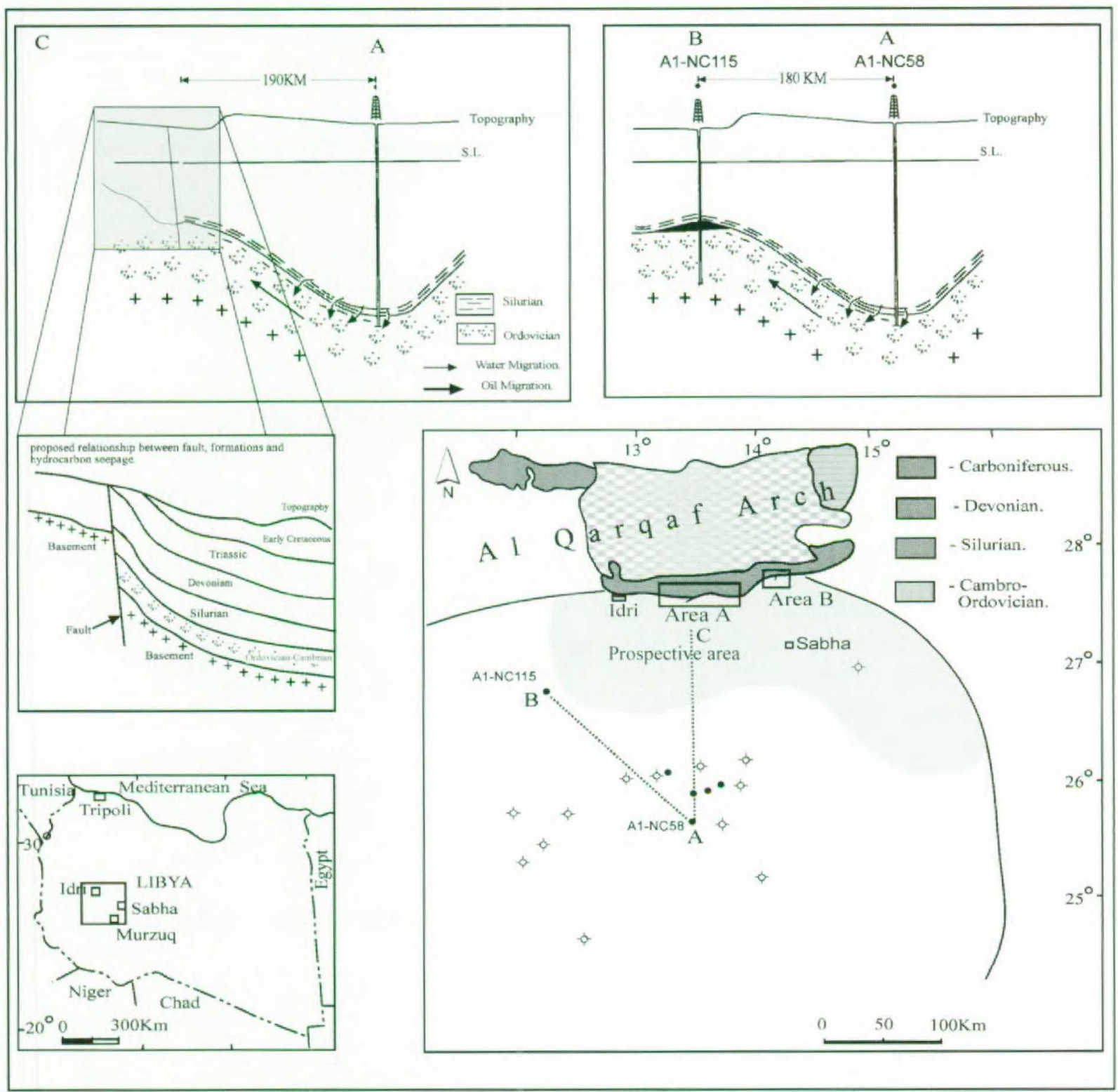

Figure 1: Location map of the study area and hydrocarbon migration and surface-cap relationship. 

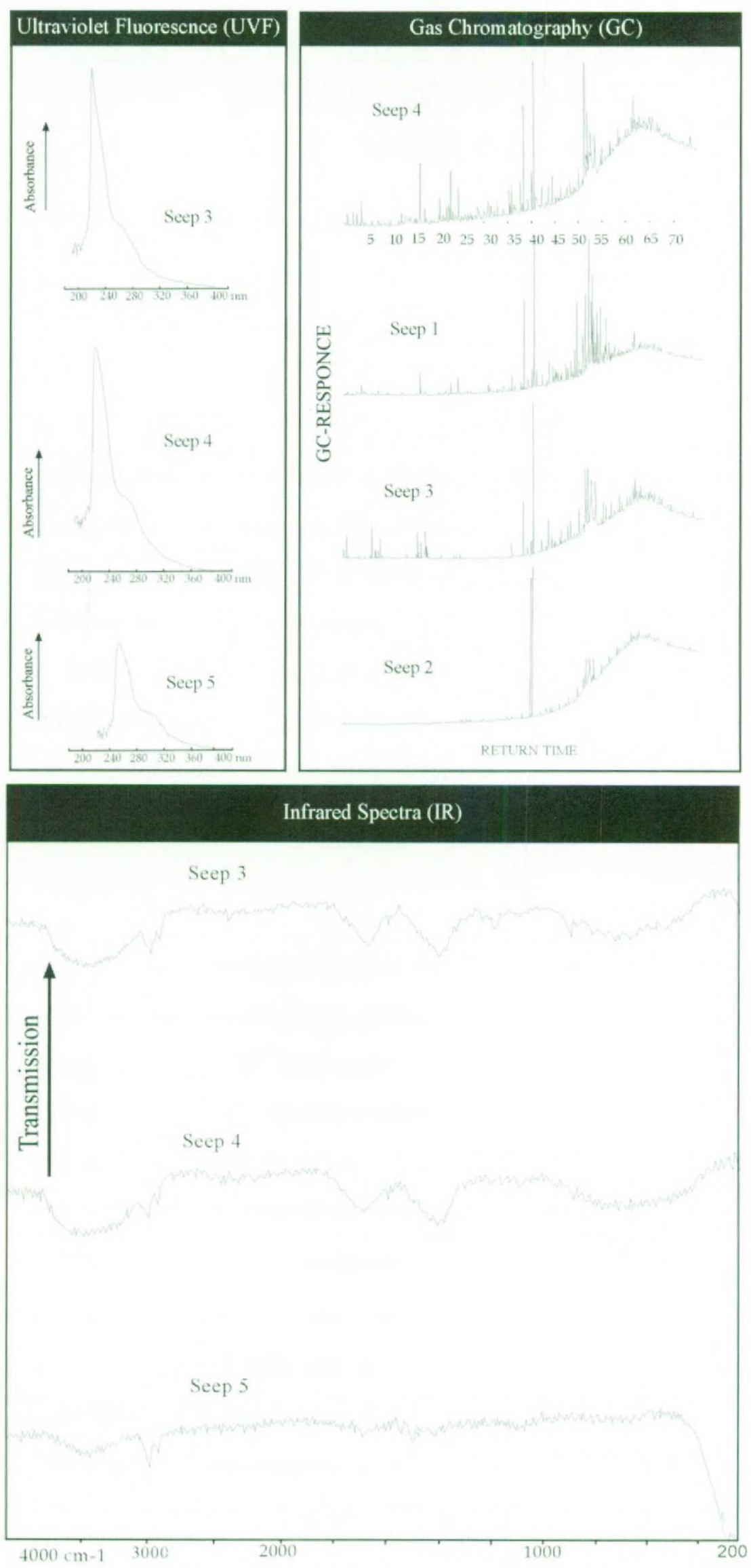

Figure 2. Ultraviolet Fluorescence (UVF), Gas Chrom atography (GC)and Infrared Spectra (IR) of selected extracts of soil samples. 